\title{
Serum Hepcidin in Patients with Chronic Hepatitis C and its Relation to Treatment with Antiviral Drugs
}

\author{
Mohamed Khamis Ali Khalil ${ }^{1, *}$ MB Bch, Ashraf Abdel Monem Sayed Ahmed ${ }^{1}$ MD, Mostafa Abdel Aziz \\ Ahmed Elhawary ${ }^{2}$ MD and Ahmed Ali Ali Assem ${ }^{1}$ MD.
}

*Corresponding Author:

Mohamed Khamis Ali Khalil

mohamad.khamis14@gmail.com

Received for publication April19, 2020; Accepted June30, 2020; Published onlineJune30, 2020.

Copyright 2020 The Authors published by Al-Azhar University, Faculty of Medicine, Cairo, Egypt. All rights reserved. This an open-access article distributed under the legal terms, where it is permissible to download and share the work provided it is properly cited. The work cannot be changed in anyway or used commercially.

doi:10.21608/aimj.2020.28247.1201

${ }^{I}$ Clinical Pathology Department, Faculty of Medicine, Al-Azhar University, Cairo, Egypt.

${ }^{2}$ Tropical Medicine Department, Faculty of Medicine, Al-Azhar University, Cairo, Egypt.

\begin{abstract}
Background: There is a relationship between HCV infection and accumulation of body iron in the liver. Iron overload has been found to be cofactor for HCV associated fibrosis and hepatocellular carcinoma. Hepcidin produced by hepatocytes, is very important in regulation of iron metabolism. Disturbances in Hepcidin concentrations have been reported in chronic HCV infection and hepatocellular carcinoma.

The aim of the work: is to measure levels of serum hepcidin in chronic hepatitis $\mathrm{C}$ patients and evaluate any association with the viral load after antiviral treatment.

Aim of work:To measure hepcidin level in chronic hepatitis $\mathrm{C}$ patients (before and after treatment with antiviral drugs) and healthy controls to assess the level of hepcidin in CHC and its relation to antiviral therapy.

Patient and methods: Our study was carried on 50 patients with chronic hepatitis C. Hepcidin levels were evaluated for Hepcidin before starting the antiviral therapy treatment (group A) andafter 24 weeks course of antiviral therapy(group B)with a commercially available enzyme-linked immunosorbent assay kits in addition to 20 apparently normal volunteers with matched age and sex as control group (group C).

Results: Regarding serum Hepcidin, there was a highly statistical significant difference between patient and control group. Hepcidin levels in $\mathrm{CHC}$ patients were low in comparision to $\mathrm{HCV}$-ve people. Highly statistical significant $(\mathrm{p}$-value $>0.05)$ positive correlation $(\mathrm{r}=0.67)$ between Hepcidin before and after treatment in patients group.

Conclusion: Chronic HCV infection is associated with low level of serum hepcidin. That effect of HCV on hepcidin level was fully reversible after antiviral treatment.
\end{abstract}

Keywords: $\mathrm{CHC}$; Hepcidin; Antiviral therapy.

Disclosure: The authors have no financial interest to declare in relation to the content of this article. The Article Processing Charge was paid for by the authors.

Authorship: All authors have a substantial contribution to the article.

\section{INTRODUCTION}

Hepatitis C virus infection is a big worldwide problem, it is estimated that more than 80 million are chronically infected globally, with 3-4 million new infections and 355,000 deaths occurring each year because of its related complications. ${ }^{1}$

It is estimated that Egypt comes first worldwide in $\mathrm{HCV}$ prevalence, with incidence rates at 2.4 per 1000 , and an estimated average of 166,000 new cases every year, according to Centers for Disease Control and Prevention (CDC). ${ }^{2}$

Infection follows a variable course; while it is often asymptomatic, some patients develop liver fibrosis

and ultimately cirrhosis, which is apparent after many years. ${ }^{3}$

Hepatitis C virus remains the leading cause of chronic liver disease, accounting for $50 \%$ to $70 \%$ of primary liver cancers. ${ }^{4}$ The incidence of chronic liver disease is increasing. ${ }^{5}$

Hepcidin was first discovered in human blood and urine samples as a bactericidal peptide and named liver expressed antimicrobial peptide (LEAP-1). ${ }^{6}$ The name 'hepcidin' originates from hepatocytes (hep) where it is synthesized and its antimicrobial activity (cidin). It has antibacterial (Escherichia coli, Staphylococcus aureus, ect) and antifungal activity (Aspergillusniger, Aspergillusfumigatus, ect). ${ }^{7}$

Hepcidin is a circulating peptide which is secreted from liver and excreted in urine. ${ }^{8}$ It causes release of iron by macrophages and hepatocytes ${ }^{9}$ It regulates serum iron level and tissue distribution of iron. It inhibits iron absorption by enterocytes in the duodenum through its binding to ferroportin and inducing its degradation. ${ }^{10}$ Theses mechanisms result in decrease of serum iron level and increased intracellular iron content. ${ }^{11}$ 
The discovery of hepcidin in $2000^{12}$ not only opened the way to understand its antimicrobial and metabolic role but also raised the possibility of use of hepcidin as a diagnostic and therapeutic tool in some diseases. The liver is the main iron storage organ. About third of the total body iron is store in hepatocyte, sinusoidal mesenchymal cells and reticuloendothelial cells. ${ }^{13}$ It plays an important role in iron metabolism and regulation, as transferrin and ferritin are synthesized here. ${ }^{14}$

The aim of this cross sectional case control study was to measure hepcidin level in chronic hepatitis C patients (before and after treatment with antiviral drugs) and healthy controls to assess the level of hepcidin in CHC and its relation to antiviral therapy.

\section{PATIENT AND METHODS}

50 patients with chronic hepatitis $\mathrm{C}$ infection were attended to tropical medicine department at $\mathrm{Al}$-Azhar University Hospitals in addition to 20 apparently healthy people were included in this study. Written informed consents were obtained from all participants.

Patients have been evaluated for hepcidin and Other parameter before starting the treatment and defined as (group A) and after treatment and defined as (group B)in addition to 20 apparently healthy individuals (group C).

Patient with the following criteria was included in the study: adult patients of both sexes with seropositivity of HCV Ab. We excluded patients with the following criteria from the study: hepatitis B virus infection, alcoholic liver disease, and associated HCC, hemochromatosis, HIV infection and renal failure. All patients were subjected to History, examination and investigations including: Liver function tests (ALT - AST), Kidney function tests (Urea Creatinine), Serum bilirubin, Hemoglobin concentration, Iron profile (Iron - Ferritin) Serum hepcidin.

In both control and patient groups, $8 \mathrm{ml}$ of venous blood will be withdrawn, $2 \mathrm{ml}$ on EDTA for CBC and the remaining amount in plain tube will be left for clotting, then centrifuged, separated serum will be divided in 2 aliquots, one used for routine investigations and the other portion will kept frozen at -80C until used for hepcidin assay using enzyme linked immunosorbent assay (ELISA), commercial kits Catalogue No. 95618, LOT No. 201907. Iron was measured using colorimetric method by DIALAB Autolyser, commercial kits Catalogue No. D01106, LOT No 8702/24999.Ferritin was measured using sandwich immunodetection method by iCHROMA II, commercial kits Catalogue No. CFPC-32, LOT No.FRPYA64 .

\section{Statistical analysis:}

Data will be analyzed by using statistical software SPSS 13.0. All the quantitative data will be expressed as mean $\pm \mathrm{SD}$, while qualitative data will be expressed as percentages. Qualitative data will be analyzed by Chi-square test or Fisher's exact test where appropriate and quantitative data by Student's t-test, ANOVA or Mann-Whitney's $U$ test. Correlation study will be done by using Spearman's correlation coefficient test. A ' $p$ ' value of $<0.05$ will be taken as statistically significant.

\section{RESULTS}

The characteristics for the studied group (A) cases (30 males and 20 females) are shown in (Table 1) which showing slightly elevated AST and ALT, bilirubin in comparison to control group while CRP, kidney function tests, were within normal range. As regard serum iron, there was highly significant decreased in S. iron level in group (A) patients with a mean of $(76.5 \pm 9.9)$ in comparison to control group $\mathrm{C}$ with a mean of $(111.5 \pm 11.8)$.

As regard S. ferritin, there was highly significant elevation in S. Ferritin level in group(A) patients with a mean of $(266.2 \pm 37.3)$ in comparison to control group with a mean of $(96.4 \pm 9.4)$.

As regard serum hepcidin, there was highly significant decrease in S. hepcidin level in group (A) patients with a mean of $(30.4 \pm 9.9)$ in comparison to control group $(\mathrm{C})$ with a mean of $(65 \pm 12.7)$. (Figure 1-3)

\begin{tabular}{|c|c|c|c|c|c|}
\hline & & Group A & Group C & Stat. test & P-value \\
\hline $\mathrm{Hb}(\mathrm{g} / \mathrm{dl})$ & Mean \pm SD & $11.9 \pm 1.5$ & $13.6 \pm 0.9$ & $T=4.4$ & $<0.001 \mathrm{HS}$ \\
\hline Urea(mg/dl) & Mean \pm SD & $29.6 \pm 12.7$ & $24.6 \pm 5.5$ & $\mathrm{~T}=1.7$ & $0.082 \mathrm{NS}$ \\
\hline Creat(mg/dl) & Mean \pm SD & $0.76 \pm 0.3$ & $0.78 \pm 0.1$ & $\mathrm{~T}=0.19$ & $0.839 \mathrm{NS}$ \\
\hline Bil. T(mg/dl) & Mean \pm SD & $1.18 \pm 0.4$ & $0.69 \pm 0.2$ & $\mathbf{T}=\mathbf{5 . 0 2}$ & $<0.001 \mathrm{HS}$ \\
\hline SGPT(U/L) & Mean \pm SD & $50.4 \pm 13.6$ & $25.8 \pm 6.2$ & $\mathrm{~T}=7.5$ & $<0.001 \mathrm{HS}$ \\
\hline SGOT(U/L) & Mean \pm SD & $67.6 \pm 25.7$ & $27.2 \pm 6.8$ & $T=6.8$ & $<0.001 \mathrm{HS}$ \\
\hline CRP(mg/L) & Mean \pm SD & $2.6 \pm 1.9$ & $2.8 \pm 1.2$ & $\mathrm{~T}=0.41$ & $0.677 \mathrm{NS}$ \\
\hline Iron(mg/dl) & Mean \pm SD & $76.5 \pm 9.9$ & $111.5 \pm 11.8$ & $T=10.8$ & $<0.001 \mathrm{HS}$ \\
\hline Ferritin(ng/l) & Mean \pm SD & $266.2 \pm 37.3$ & $96.4 \pm 9.4$ & $T=19.8$ & $<0.001 \mathrm{HS}$ \\
\hline Hepcidin & Mean \pm SD & $30.4 \pm 9.9$ & $65 \pm 12.7$ & $\mathrm{~T}=\mathbf{1 0 . 2}$ & $<0.001 \mathrm{HS}$ \\
\hline
\end{tabular}

T: independent sample T test.HS: p-value $<0.001$ is considered highly significant. NS: p-value $>0.05$ is considered non-significant.

Table 1: Comparison between group (A) patients \&groups (C) as regard laboratory data. 
Former table shows:

-No statistical significant difference (p-value $>0.05$ ) between control and patients groups regarding urea, creat and CRP.

- Highly statistical significant difference (p-value < 0.001 ) between control and patients groups regarding Bil. T, SGPT, SGOT, Iron, ferritin and hepcidin.

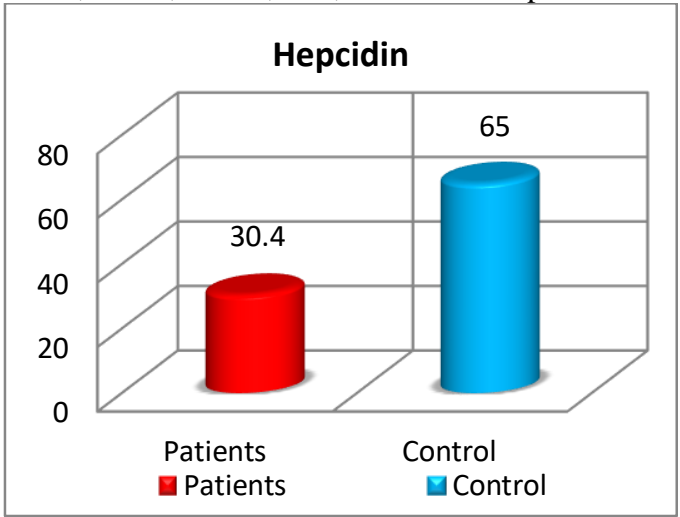

Fig. 1: Comparison between patients group $A \&$ Control groups $\mathrm{C}$ regarding Hepcidin.
To evaluate direct effect of antiviral therapy on hepcidin level, iron indices, laboratory investigations were determined in group (B) patients(after 24 weeks course of antiviral therapy) and compared with those of group (A) patients (before treatment) as shown in (Table 2,3).

Serum hepcidin levels were significantly increased from $(30.4 \pm 9.9)$ to $(95.6 \pm 12.5)$ with P-value < $0.001 \mathrm{HS}$. Serum ferritin levels were increased from $(266.2 \pm 37.3)$ to $(343.4 \pm 29.3)$ with significant improvement of serum iron from $(76.5 \pm 9.9)$ to $(100.6 \pm 8.1)$

Also AST and ALT were significantly decreased from $(67.6 \pm 25.7)$ and $(50.4 \pm 13.6)$ to $(47.2 \pm 11.7)$ and $(38.2 \pm 7.3)$ respectively. There was significant improvement of $\mathrm{Hb}$ concentration from $(11.9 \pm 1.5)$ to $(12.9 \pm 1.3)$.

\begin{tabular}{|c|c|c|c|c|c|}
\hline & & \multicolumn{2}{|c|}{ HCV Patients } & \multirow{2}{*}{ Stat. test } & \multirow{2}{*}{ P-value } \\
\hline & & Group A & Group B & & \\
\hline $\mathrm{Hb}(\mathrm{g} / \mathrm{dl})$ & Mean \pm SD & $11.9 \pm 1.5$ & $12.9 \pm 1.3$ & $\mathrm{~T}=\mathbf{2 . 8}$ & $0.007 \mathrm{~S}$ \\
\hline Urea(mg/dl) & Mean \pm SD & $29.6 \pm 12.7$ & $30.1 \pm 9.4$ & $\mathrm{~T}=0.16$ & $0.87 \mathrm{NS}$ \\
\hline Creat(mg/dl) & Mean \pm SD & $0.76 \pm 0.3$ & $0.9 \pm 0.2$ & $\mathrm{~T}=1.8$ & $0.068 \mathrm{NS}$ \\
\hline Bil. T(mg/dl) & Mean \pm SD & $1.18 \pm 0.4$ & $1.02 \pm 0.3$ & $\mathrm{~T}=1.6$ & $0.125 \mathrm{NS}$ \\
\hline SGPT(U/L) & Mean \pm SD & $50.4 \pm 13.6$ & $38.2 \pm 7.3$ & $T=3.9$ & $<0.001 \mathrm{HS}$ \\
\hline SGOT(U/L) & Mean \pm SD & $67.6 \pm 25.7$ & $47.2 \pm 11.7$ & $T=3.6$ & $0.001 \mathrm{~S}$ \\
\hline CRP(mg/L) & Mean \pm SD & $2.6 \pm 1.9$ & $2.5 \pm 1.1$ & $\mathrm{~T}=0.19$ & $0.845 \mathrm{NS}$ \\
\hline Iron(mg/dl) & Mean \pm SD & $76.5 \pm 9.9$ & $100.6 \pm 8.1$ & $\mathrm{~T}=9.4$ & $<0.001 \mathrm{HS}$ \\
\hline Ferritin(ng/l) & Mean \pm SD & $266.2 \pm 37.3$ & $343.4 \pm 29.3$ & $T=8.1$ & $<0.001 \mathrm{HS}$ \\
\hline Hepcidin & & $30.4 \pm 9.9$ & $95.6 \pm 12.5$ & $\mathbf{T}=\mathbf{2 0 . 3}$ & $<0.001 \mathrm{HS}$ \\
\hline
\end{tabular}

T: independent sample T test.S: p-value $<0.05$ is considered significant. HS: p-value $<0.001$ is considered highly significant.NS: $\mathrm{p}$-value $>0.05$ is considered non-significant.

Table 2: Comparison between patients (before \& after treatment) as regard laboratory data.

This table shows:

- No statistical significant difference (pvalue $>0.05$ ) between patients (before \& after therpy) groups regarding urea, creat, Bil T \& CRP.

- Highly statistical significant difference (pvalue $<0.001$ ) between patients (before \& after therapy) regarding SGPT, Iron, ferritin and hepcidin.

- Statistically significant difference (p-value $<0.05$ ) between patients (before \& after thrapy) regarding Hb\& SGOT. 


\begin{tabular}{|c||c||c|}
\hline Variables & (r) & p-value \\
\hline \hline $\begin{array}{c}\text { Hepcidin } \\
\text { (before vs after } \\
\text { treatment) }\end{array}$ & $\mathbf{0 . 6 7}$ & $<\mathbf{0 . 0 0 1} \mathrm{HS}$ \\
\hline
\end{tabular}

(r): Pearson correlation coefficient.

Table 3: Correlation study between Hepcidin in patients (before and after treatment).

This table shows:

-Highly statistical significant (p-value > 0.05) positive correlation.

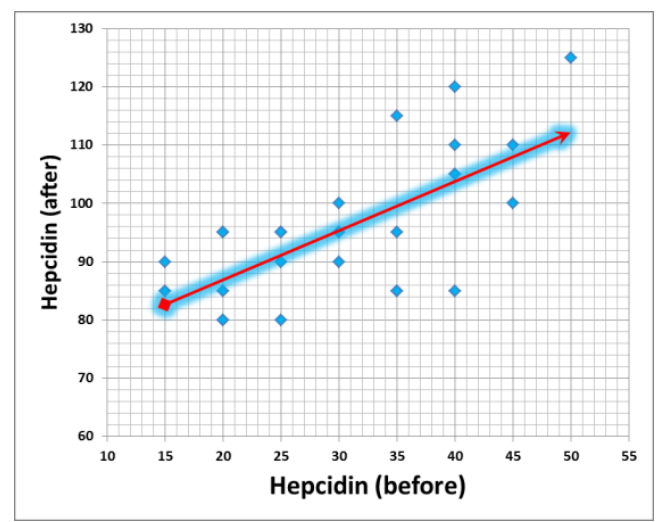

( $\mathbf{r}=\mathbf{0 . 6 7}$ ) between Hepcidin (before vs after) in patients group.

Fig. 3:positive correlation between Hepcidin (before vs after treatment) in patients group.

\section{DISCUSSION}

Hepatitis $\mathrm{C}$ virus infection is considered to be one of the main causes of chronic liver disease all over the world. ${ }^{4}$

The effect of HCV infection on the liver varies from minimal changes to chronic hepatitis and cirrhosis with or without hepatocellular carcinoma. The number of chronic HCV infected cases all over the world may be approximately 177 million. ${ }^{15}$

Although the main factor which causes initiation of hepatic disease processes in chronic hepatitis patients is $\mathrm{HCV}$ infection, it has become clear that involvement of cofactors is critical in determining the progression of this disease. Chronic HCV infection appears to be associated with iron homeostasis disturbances, with increased serum ferritin and hepatic iron stores in nearly $50 \%$ of patients. ${ }^{16}$

Hepcidin is iron regulatory hormone; it is synthesized mainly in hepatocytes. Hepcidin synthesis is increased by iron overload and decreased by anemia and hypoxia. Moreover, it is also induced by infection and inflammation. ${ }^{17}$

Disturbance in hepcidin regulation has been reported as a possible mechanism causing iron overload in some conditions, such as alcoholic liver disease ${ }^{18}$ and CHC. ${ }^{19}$

Our study was conducted to estimate the level of serum hepcidin, iron and ferritin in chronic hepatitis $\mathrm{C}$ patients (CHC) and the effect of antiviral treatment on them.

Regarding the sex distribution of the studied cases males were predominant, although patients were selected randomly. This is in agreement with the study conducted in the National Research Center, Cairo, Egypt by Moataza, ${ }^{20}$ this may be related to social risk factors for HCV transmission as drugs and occupational exposure.

In our study CHC patients of group (A) had elevated ALT and AST similarly; Kwo ${ }^{21}$ found that $43 \%$ of $\mathrm{HCV}$ antibody positive applicants had liver enzyme elevations less than 2 times normal.

We also studied the relation between liver enzymes (ALT, AST) and baseline hepcidin levels for group (A) studied cases and we found that there was no significant correlation between hepcidin levels and liver enzymes ALT and AST.

In agreement with our results, Fujita ${ }^{22}$ found that there were no significant correlations between serum hepcidin levels and serum transaminase (AST and ALT).

In contrast, Tsochatzis ${ }^{23}$ concluded that in patients with chronic $\mathrm{HCV}$, serum hepcidin correlated positively with (AST) and with (ALT).

As regard serum iron, there was highly significant decreased in S. iron level in group (A) CHC patients in comparison to control group. These results were in agreement with Marzouk ${ }^{24}$ and El Lehleh ${ }^{25}$ who found that serum iron was decreased in $\mathrm{CHC}$ patients compared to control group.

Also, these results were in agreement with Fujita $^{22}$ who found that mild anemia was a complication in CHC patients. This anemia may also affect the diminished hepatic hepcidin production in these patients.

However, these results did not agree with Mohamed ${ }^{26}$ who concluded that serum iron was higher in chronic hepatitis $\mathrm{C}$ patients in comparison to control group. These discrepancies may be because of the low number of patients and the difference in number of patient groups in stages of liver diseases.

As regard S. ferritin, there was highly significant increase in S. Ferritin in group (A) CHC patients with a mean of $(266.2 \pm 37.3)$ in comparison to control group with a mean of $(96.4 \pm 9.4)$.

Our results agreed with Oikonomou ${ }^{27}$ who found high serum ferritin in chronic hepatic patients which is associated with worse outcomes in patients with decompensated cirrhosis. Also Pietrangelo ${ }^{28}$ reported that serum ferritin was higher in $\mathrm{CHC}$ cirrhotic patients than controls and the levels also correlated with the severity of the disease. 
As regard serum hepcidin, there was highly significant decrease in S. hepcidin level in group (A)CHC patients with in comparison to control group.

This agrees with Mohamed ${ }^{26}$ who found that Serum hepcidinwas lower in chroinc hepatitis $\mathrm{C}$ patients than in control group.

Also, our results were in agreement with Terrence ${ }^{29}$ who made a study on patients with CLD and healthy controls. They found that patients with cirrhosis had significantly lower hepcidin and compared with those without cirrhosis.

Pietrangelo ${ }^{28}$ reported a decrease in serum hepcidin along with increased serum ferritin in decompensated cirrhotic and the levels also correlated with the severity of the disease.

Also This agrees with Girelli ${ }^{30}$ who reported lower serum hepcidin in chronic hepatitis $\mathrm{C}$ patients than in control group.

However our results did not agree with Fujita ${ }^{22}$ who found that there is no significant difference in hepcidin levels between chronic hepatitis $\mathrm{C}$ patients and control group, maybe due to low number of controls enrolled .Regarding to the improvement of serum hepcidin levels after 24 weeks of treatment with antiviral drugs, we found significant increase in serum hepcidin after therapy. This goes in agreement with Ismail ${ }^{31}$ who found That diminished level of serum hepcidin in $\mathrm{CHC}$ was fully reversible after successful eradication of $\mathrm{HCV}$ following therapy. Fujita $^{22}$ also found that serum hepcidin levels were elevated after antiviral treatment.

In our study, serum ferritin and serum iron levels of patients were increased after 24 weeks with antiviral treatment compared to the base line. This goes in agreement with Bazeed ${ }^{32}$ who reported increase in ferritin and iron in $\mathrm{CHC}$ patients after antiviral therapy.

On the contrary, Fujita ${ }^{22}$ found that when the patients were assigned to SVR, they were recovered from iron overload status with reduction of serum ferritin level. This may be due tothe lag of reduction of serum ferritin after initial improvement of serum hepcidin levels and also follow up of our patient after achievement of sustained virological response may be associated with normalization of serum ferritin levels.

\section{CONCLUSION}

From the current study we can conclude that chronic $\mathrm{HCV}$ is associated with diminished level of serum hepcidin, however this reduced level is fully reversible with antiviral therapy. Also the initial rise of serum hepcidin could be used as an indicator of patients response to therapy although we recommend a wider scale study (regarding patients numbers and duration) for a better understanding of the prognostic and monitoring role of hepcidin among chronic $\mathrm{HCV}$ patients on antiviral therapy.

\section{REFERENCES}

1. Gower E, Ester C, Blash S, et al. Global epidemiology and genotype distribution of the hepatitis C virus infection: J Hepatol. 2014; 61:45-57.

2. Centers for Disease Control and Prevention. Progress toward Prevention and Control of Hepatitis C Virus Infection: Egypt, 20012012.MMWR. 2012; 61 (29):545, 6.

3. Feld JJ and Liang TJ. Hepatitis C-identifying patients with progressive liver injury: Hepatology. 2006;43: 194-206.

4. Reddy KR. Hepatitis C virus: The Next Epidemic. An Issue of Gastroenterology Clinics of North America, 1st Edition book. www. Gastro. Theclinics.com.2015; 15: 44-52.

5. Kim Y, Ejaz A, Tayal A, et al. Temporal trends in population - based death rates associated with chronic liver disease and liver cancer in the united states over the last $30 \mathrm{y}$ : cancer. 2014; $120: 3058-65$.

6. Kanda J, Mizumoto C, Kawabata H, et al. Serum hepcidin level and erythropoietic activity after hematopoietic stem cell transplantation: Haematologica. 2008; 93: 1550-4.

7. Politou M, Papanikolaou G. Hepcidin: A key iron regulator involved in the pathogenesis of anaemia of chronic disease: Haema. 2004; 7 : 165-74.

8. Mohamed S.M, Morsy, A.A.E.A, Mohamed N.M.B.E.D and Mohamed A.R. Estimation of Serum Hepcidin and Ferritin in Patients with Chronic Liver Disease: The Egyptian Journal of Hospital Medicine. 2019; 74(8), pp.1817-25.

9. Ganz, T. Systemic iron homeostasis: Physiological reviews. 2013; 93(4), pp.172141.

10. Przybyszewska J, and Żekanowska, E. The role of hepcidin, ferroportin, HCP1, and DMT1 protein in iron absorption in the human digestive tract: Przeglad gastroenterology iczny. 2014; 9(4), p.208.

11. Michels K, Nemeth E, Ganz T, and Mehrad B. Hepcidin and host defense against infectious diseases: PLoS pathogens. 2015; 11(8).

12. Krause A, Neitz S, Mägert HJ, et al. LEAP-1, a novel highly disulfidebonded human peptide, exhibits antimicrobial activity: FEBS Lett. 2000; 480: 147-50. 
13. Mitsuyoshi H, Yasui K, Yamaguchi K, et al. Pathogenic role of iron deposition in reticulendothelial cells during the development of chronic hepatitis C: Int J Heptol. 2013; 68620-8.

14. Anastasiou O.E, Kälsch J, Hakmouni M, et al. Low transferrin and high ferritin concentrations are associated with worse outcome in acute liver failure: Liver International. 2017; 37(7), pp.1032-41.

15. Petruzziello A, Marigliano S, Loquercio G, et al. Global epidemiology of hepatitis $\mathrm{C}$ virus infection: An up-date of the distribution and circulation of hepatitis $\mathrm{C}$ virus genotype: World J Gastroentrol. 2016; 22(34): 7824-40.

16. Zou DM and Sun WL. Relationship between Hepatitis $\mathrm{C}$ virus infection and iron overload: Chinese Medical Journal. 2017; 130(7):86671.

17. Jaroszewicz J, Rogalska M, Flisiak I, et al Successful antiviral therapy is associated with a decrease of serum prohepcidin in chronic hepatitis C: World J Gastroenterol. 2010; 16(14): 1747-52 .

18. Bridle K, Cheung TK, Murphy $\mathrm{T}$, et al Hepcidin is down-regulated in alcoholic liver injury: implications for the pathogenesis of alcoholic liver disease: Alcohol ClinExp Res. 2006; 30:106-12.

19. Nishina $\mathrm{S}$, Hino $\mathrm{K}$, Korenaga $\mathrm{M}$, et al. Hepatitis C virus-induced reactive oxygen species raise hepatic iron level in mice by reducing hepcidin transcription: Gastroenterology. 2008; 134:226-38 .

20. Moataza H.O, Samar S.Y, Wael T, Phylogenetic and Genotyping of Hepatitis C Virus in Egypt: Australian Journal of Basic and Applied Sciences. 2009; 3(1): 1-8.

21. Kwo P.Y, Cohen S.M, and Lim J.K. ACG clinical guideline: evaluation of abnormal liver chemistries: American Journal of Gastroenterology. 2017; 112(1), pp.18-35.

22. Fujita N, Sugimoto R, Motonishi $S$, et al. Patients with chronic hepatitis $\mathrm{C}$ achieving a sustained virological response to peginterferon and ribavirin therapy recover from impaired hepcidin secretion: J Hepatol. 2008; 49: 70210 .

23. Tsochatzis E, Papatheodoridis G.V, Koliaraki $\mathrm{V}$, et al. Serum hepcidin levels are related to the severity of liver histological lesions in chronic hepatitis C: Journal of Viral Hepatitis. 2010; 17: 800-6.
24. Marzouk H.A, Zayed N.A, Al-Ansary M, et al. Hepcidin levels in Egyptian patients with chronic hepatitis $\mathrm{C}$ and the effect of anti-viral therapy: World Applied Sciences Journal. 2013; 22(8):1140-5.

25. El Lehleh A.M, El Shazly R.A and Hamza R.R. Study of serum hepcidin in patients with chronic heoatitis C: Menoufia Medical Journal. 2017; 30(3):721-6.

26. Mohamed F.S, Elkady M.M, El-Fedawy M, et al. Study of serum hepcidin, iron and ferritin in chronic hepatitis C patients: American Journal of Medicine and Medical Sciences. 2014; 4(6):283-6.

27. Oikonomou T, Goulis L, Cholongitas E, et al. High serum ferritin is associated with worse outcomes of patients with decompensated cirrhosis: Annals of Gastroenterology. 2017; 30(2): 217-24.

28. Pietrangelo A, Cohen L.A, Waidmann O, et al. Reply to: Ferritin in decompensated cirrhosis: iron or inflammation: Journal of Hepatology. 2015; 62:492-501.

29. Terrence C.H, Darreell H.G, Michael E, et al. The serum hepcidin: ferritin ratio is a potential biomarker for cirrhosis: Liver International. 2012; 32(9):1391-9.

30. Girelli D, Michela P, Julia B, et al. Reduced serum hepcidin levels in patients with chronic hepatitis C: Journal of Hepatology. 2009; 51: 845-52.

31. Ismail H.A, Ebrahim D, El-Assal M.A, et al. Predictive value of hepcidin in patients with chronic hepatitis $\mathrm{C}$ infection among Egyptians: Egyptian Liver Journal. 2018; 8(1), pp.12-6.

32. Bazeed F, Elsherbeny H, Elsayed M, et al. Evaluation of serum iron and ferritin in different treatment regimens for chronic hepatitis C virus: IOSR J of pharmacy and Biological Sciences (IOSR-JPBS). 2016; 11(4), pp.13-9. 